\title{
DESCRIPTIONS OF NEW SPECIES AND GENERA OF WEST AFRICAN LEPIDOPTERA.
}

\author{
BY W. J. HOLland, PH. D., PitTSBURGh, PENN.
}

The species described in the following paper are all from the Valley of the Ogové River except when otherwise indicated. The types are in my collection.

\section{AGARISTIDAE.}

Phasis, Walk.

ז. P. (?) astrapeus, sp. nov. $\delta$. The palpi are pale brown beneath and black above. The pectus is broadly orange, and the front legs are narrowly edged with the same color. The rest of the body above and below is black, except that the eyes on the inner margin are narrowly edged with white. The wings above are velvety black, the anteriors crossed beyond the cell by a moderately broad and even band of sulphur yellow, which does not reach the costa, and terminates abruptly before the outer angle; the posteriors have a broad tapering band of the same color running from the base and terminating before the inner angle. This band which does not touch the costa, has its outer margin convex and its inner margin straight. The markings of the wings are upon the under side as upon the upper, and in addition there is a quadrate whitish spot at the end, and a yellow ray at the base, of the cell of the primaries, and a yellow basal ray is found upon the costa of both wings. Expanse, 53 $\mathrm{mm}$.

9. The female does not differ from the male except that the wings are broader and the antennae are not swollen before the end, but filiform.

I refer this species with a shade of doubt to the genus Phasis, though in its structure, so far as ascertainable without dissection, and in its markings upon the upper side, it nearly resembles $P$. tribuna, Hübner, from the Antilles.

\section{Aegocera, Latr.}

2. A. Gladiatoria, sp. nov. $\delta$. Palpi brown, front light orange, collar and upper sides of thorax maroon, traversed by a median band of pale orange. The pectus and the abdomen orange, with a median line of maroon upon the upper side of the abdomen. The forewings upon the upper side are rich maroon. From the base to the middle of the wing just below the cell is a horizontal sword-shaped band of pearly white and a broad subapical transverse band of the same color not quite reaching the costa and tapering off before reaching the outer angle. A faint $V$-shaped mark appears upon the dark ground of the wing near the costa just before the subapical white band and there is also a faint submarginal line of the same color. The upper side of the posteriors is pale orange broadly margined with brown, the margin widest near the outer angle. The bolder markings of the upper side are reproduced upon the under side, but paler and less sharply defined.

ㅇ. The female does not differ from the male except that she is much larger.

Expanse of wings, § $35 \mathrm{~mm}$.; $\& 45 \mathrm{~mm}$.

\section{CHALCOSIIDAE.}

Anamoeotes, Feld.

3. A. tenellula, sp. nov. $\delta$. Antennae brown. Body and legs red. Wings semitranslucent, with the costa of the primaries 
and the apical half of both primaries and secondaries fuscous.

․ Marked exactly as the male, but larger. Expanse of wings, $\delta 28-32 \mathrm{~mm}$; क 40 $\mathrm{mm}$.

A closely allied, if not identical, species is in the British Museum, unnamed, from Angola.

4. A. leucolena, sp. nov. $\delta$. Antennae fuscous at extremity, fulvous at base. Body fulvous. The wings are semi-translucent, white, with the primaries broadly black upon the apical third, and the secondaries almost imperceptibly touched with the same color at the extremities of the nervules.

+ . Marked as the male, but larger.

Expanse of wings, o $30-35 \mathrm{~mm}$; \& $35 \mathrm{~mm}$.

\section{ZYGAENIDAE.}

\section{Adscita, Retz.}

5. A. chloauges, sp. nov. §. Antennae long, terete, enlarged before the extremity, black. The front is bronze red. The rest of the body and the legs are black glossed with scales of metallic green. The anterior wings upon the upper side are very dark brown or black, and are glossed with patches of metallic green scales as follows: a narrow linear patch above the cell upon the costa, a couple of broad roundish patches beyond the cell near the apex, and a somewhat interrupted linear streak below the cell above the submedian nervule. The secondaries, which are rounded at the outer and inner angles, and have the outer margin somewhat deeply excavated near the extremity of the first median nervule are translucent, hyaline, except upon the costa and outer margin, which are heavily bordered with black, except at the end of the second median nervule, where the border is comparatively narrow. Expanse, $24 \mathrm{~mm}$.

I refer this species with much doubt to the genus Adscita, Retz., (Procris, Auct.Ino, Auct.). It may constitute, as Mr. Butler has suggested to me, the type of a new genus, but until $I$ have sufficient material to make dissections, and also to characterize the female sex, I do not feel justified in erecting a genus for the reception of this single species.

\section{Pollanisus, Walk.}

6. P. obscurissimus, sp. nov. $\delta$. Superficially scarcely distinguishable from $P$. cyanota, Meyr. from Sydney, N. S. Wales. The antennae are tipped with white upon the under side. The palpi, the tibiae, and the under side of the abdomen are yellowish white. 'The remainder of the body and the wings, both above and below, are smoky brown.

. Differs from the male merely in wanting the strong pectinations of the antennae, and in having less white upon the lower surface of the abdomen. Expanse, I4-15 $\mathrm{mm}$.

\section{Syntomis, Ochs.}

7. S. Ogovensis, sp. nov. §. Near $S$. Natalii, Boisd., from which it differs in having no translucent spot near the base of the primaries, and the transparent spot at the base of the secondaries is situated upon the inner margin of the wing, and not upon the cell as in S. Natalii. There is further no red band upon the abdomen as in Boisduval's species, and it is also slightly smaller in size. The color of the body and wings is black glossed with shining green. The antennae are tipped with white. There are five translucent spots upon the primaries; a round one at the end of the cell, another round one near the middle of the inner margin, and three forming a curved subapical series, the uppermost spot in which is round, and the two lower ones are oblong and divergent. There are two spots on the secondaries, a round one beyond the end of the cell near the outer margin, and a semi-lunar spot upon the inner margin at the base.

q. The female is marked as the male. Expanse, $28 \mathrm{~mm}$. 
8. S. leugalea, sp. nov. §. Very near $S$. constricta, Butl., from which it may be distinguished by its smaller size, and the more pointed apices of the primaries, which are tipped with white. Otherwise it corresponds very nearly to Mr. Butler's species, with the type of which I have compared it. Expanse, $25 \mathrm{~mm}$.

9. S. elasson, sp. nov. §. The outer margin of the primaries is strongly convex, and the apex is rounded. The basal half of the wing is vitreous. The outer half is black with a subapical series of three large, simple, oval, vitreous spots, the lower one merely separated from the hyaline space enclosed within the cell by the discocellular nervule. The costa and the inner margin are narrowly bordered with black, and the apex is tipped with white. The secondaries have no black border upon the inner margin, but are bordered upon the outer margin with black, broadly at the outer angle and then more narrowly, until the region of the submedian nerve where the black border is produced inwardly at its termination in a strong denticulation. The body and other appendages besides the wings are dark brown, almost black, except the tips of the antennae, the rront, the patagiae, the inner margins of the femora, the tibiae, the first tarsal joint, the lower edge of the abdomen, and two bands about the abdomen, which are all white. Expanse, 2I $\mathrm{mm}$.

10. S. elachista, sp. nov. $\delta$. The primaries are marked as those of $S$. elasson. The secondaries are solidly black except near the outer angle where there is a round translucent spot, and on the inner margin, where there is a similar spot. The antennae are black. The collar, the thorax, and the abdomen upon the upper side are black. The front, the inner margins of the coxae and the tibiae, the under side of the abdomen, except the last four segments, and two annular bands surrounding the abdomen, one just after the thorax, and the other on the fifth segment from its extremity, are all white.

q. The female only differs from the male in being larger in size, and having the primaries more rounded at the apex. Expanse, of $18 \mathrm{~mm}$; $q 20 \mathrm{~mm}$.

II. S. miserabilis, sp. nov. §. Marked in all respects as $S$. elasson, except that the secondaries have the entire margin surrounded with a narrow black band, and the primaries are not tipped with white at the apex, as in that species, and the subapical spot is divided into two by the first subcostal nervule. Expanse, $23 \mathrm{~mm}$.

12. S. puncticincta, sp. nov. + . The wings are marked as in the preceding species, having the uppermost spot of the subapical series divided into two, and the lowermost spot of the three simply separated from the hyaline space of the cell by the discocellular nervule. The abdomen has the segments except the last four edged with white upon the under surface. Upon the fifth and sixth segments, reckoning from the extremity of the body, there are small lateral white spots, and upon the segment next to the thorax there are two similar spots, one on each side, and a third one above upon the middle line of the abdomen. The anal extremity is tipped with orange hairs. Expanse, $25 \mathrm{~mm}$.

I3. S. leimacis, sp. nov. $\hat{\delta}$. The wings are narrow and produced, and the hyaline spaces which are arranged as in the preceding species are compressed and linear. The last spot of the subapical series is separated from the hyaline space in the cell by a moderately broad band of black scales. The color of the wings is bluish hyaline with black markings. The apex of the primary is not tipped with white. The antennae are white at the ends, as is also the front. The pectus is pale yellow, and so also the lower side of the abdomen. The patagiae, the inner edge of the coxae and tibiae, the sides. 
before the anal extremity, and the anal tuft are bright orange. The remainder of the body and its ambulatory appendages are deep black. The abdomen of the male is greatly compressed after the thorax as far as the fifth segment from the end, where it is suddenly enlarged.

. The female is marked much as the male, but the wings are broader and the body is stout. The entire head and collar are orange, and there is an orange annular band surrounding the abdomen on the fifth segment from the end. Expanse, $\delta$ and $\$ 23$ $\mathrm{mm}$.

Described from a pair taken in coitu Feb. 2oth, I 888 .

14. S. Goodii, sp. nov. \$. The wings are pointed at the apex of the primaries, and the outer margin of the primaries is only very slightly convex. The outer two-thirds of the primaries is heavily velvety black, marked by two moderately large hyaline spots, of which the uppermost, situated near the costa, about one-third of the distance from the apex is triangular, and the lower, which is suboval, is bisected by the second median nervule. The black area of the outer part of the wing is separated from the basal third, which is vitreous, by a line running from the costa perpendicularly to the inner margin near the middle. The inner margin of the clear space at the base of the primaries is narrowly bordered with black. The secondaries are heavily bordered with black at the outer angle and along the outer margin and very narrowly bordered with the same color along the inner margin. The marginal band is produced inwardly at the extremity of the first median nervule. The antennae are tipped with white. All of the remainder of the body and its appendages are black glossed with bluish green, except the inner margins of the coxae and tibiae, and the edges of the ventral segments upon the lower side, which are margined with white. Expanse, $25 \mathrm{~mm}$.

15. S. reutlingeri, sp. nov. $\&$. Allied to the preceding species. It differs from it in that the broad black area covering the outer two-thirds of the wing is defined in wardly by a line running from the costa diagonally to the outer angle, and not perpendicularly to the middle of the inner margin as in $S$. Goodii. Furthermore the hyaline spots of the apical region are much larger and the upper triangular spot is bisected by the first subcostal nervule, so that by reason of the bisection of the lower spot by the second median nervule, there is produced the appearance of four spots in this part of the wing. The secondaries are very narrowly and evenly margined with black. The front is white. The entire body, the antennae and the legs, are uniformly dull black, without any lighter markings. Expanse, $27 \mathrm{~mm}$.

16. S. leucerythra, sp. nov. $\$$. The anterior wings are strongly convex on the exterior margin, and rounded at the apex. Upper side. The prevalent color of the anterior wings, the thorax, and the abdomen is orange-rufous. The front, the posterior wings, and a band behind the thorax are paler yellowish red. Both the primaries and secondaries are very narrowly and evenly margined with light brown. The anterior wings are marked by five hyaline spots, bordered externally by light brown. They are as follows: Three, forming a transverse, curved, median series, the uppermost spot in which is quadrate, and lies at the end of the cell, the second subtriangular, and situated below the cell before the origin of the first median nervule, and the third oval and lying between the submedian nerve and the first median nervule; a subtriangular spot situated near the costa, one-third of the distance from the apex to the base, bisected by the first subcostal nervule; and a large oval spot situated near the middle of the outer margin, and bisected by the second median nervule. The posterior wings are immaculate. Under side. The basal third of the primaries and the entire surface of the 

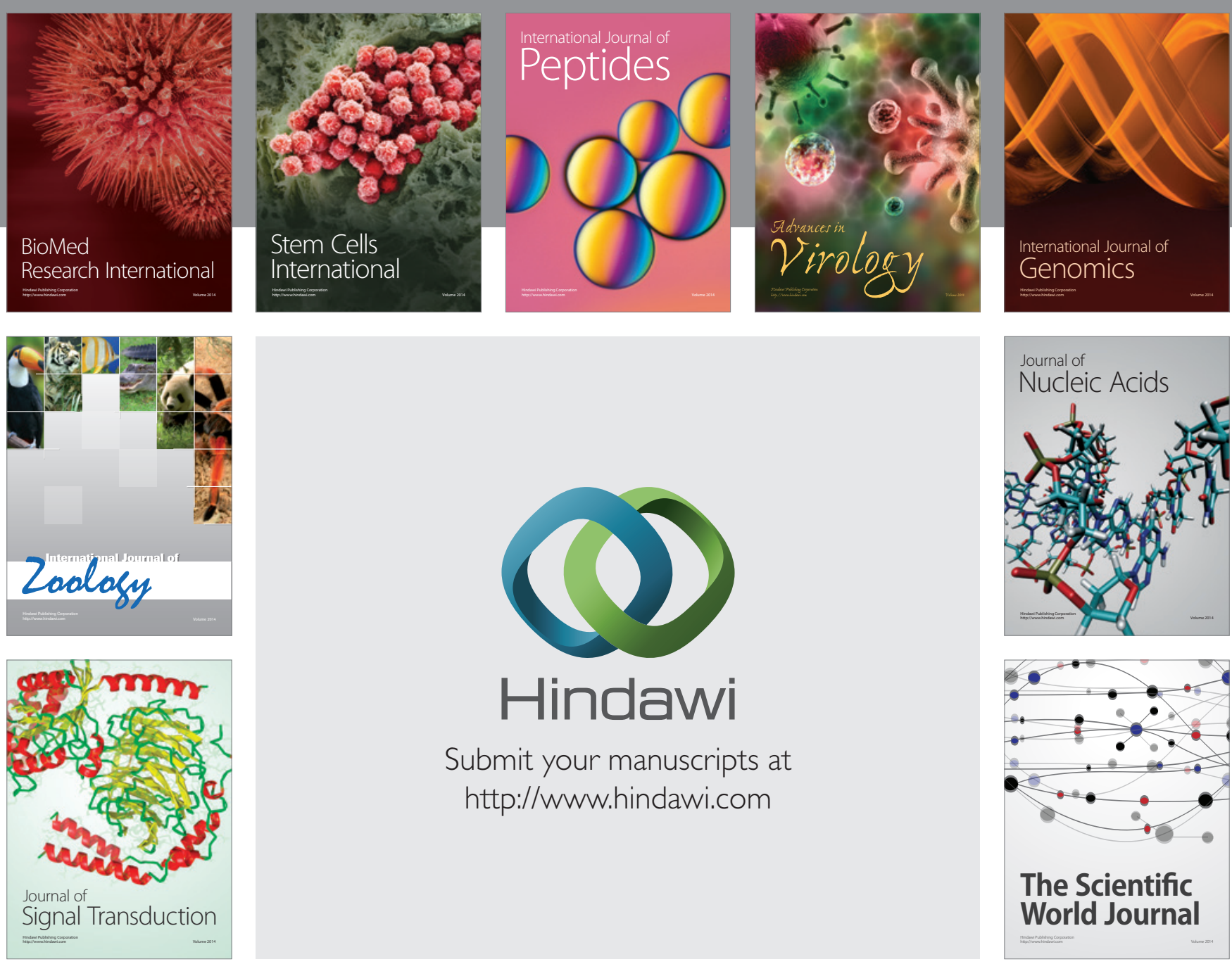

Submit your manuscripts at

http://www.hindawi.com
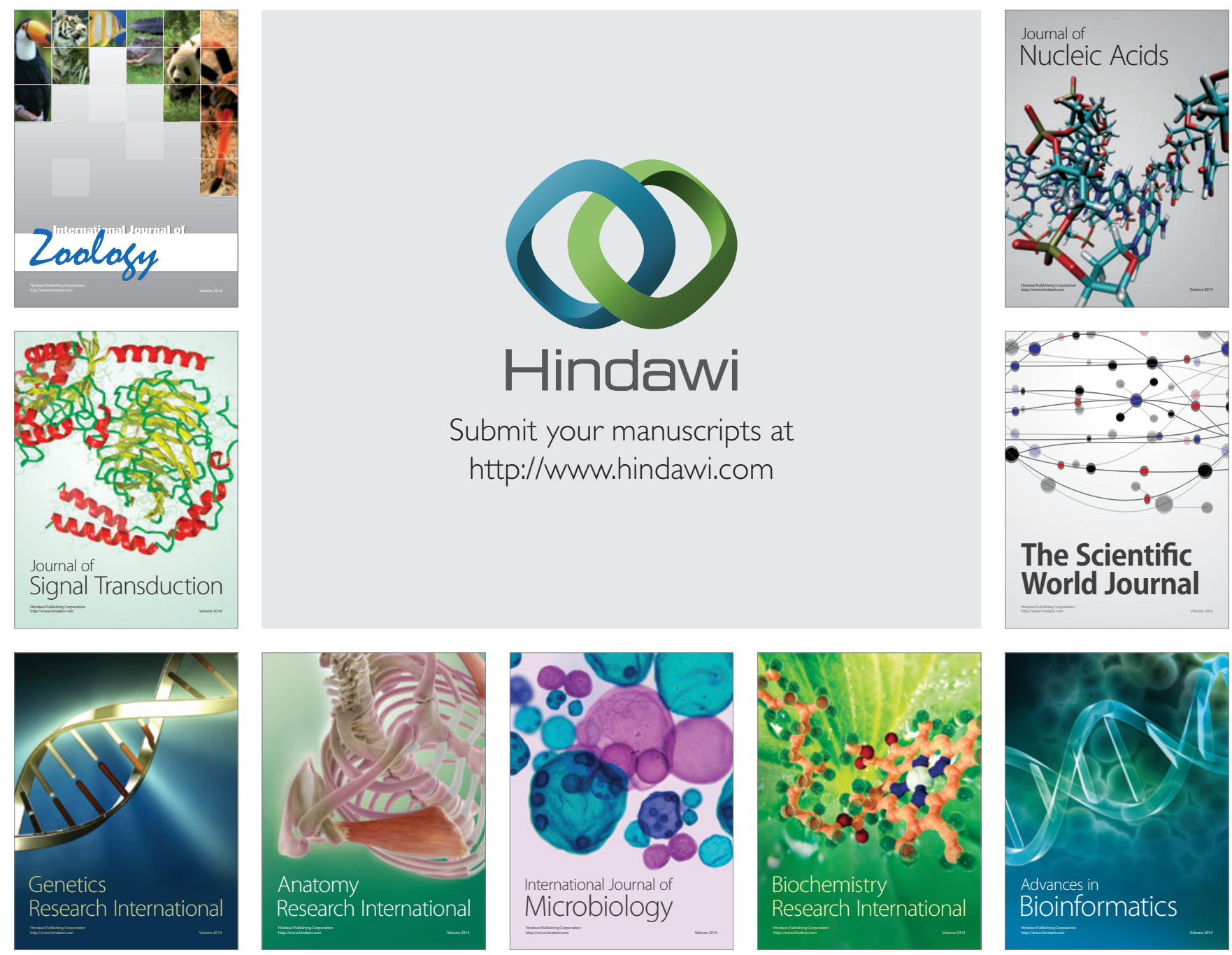

The Scientific World Journal
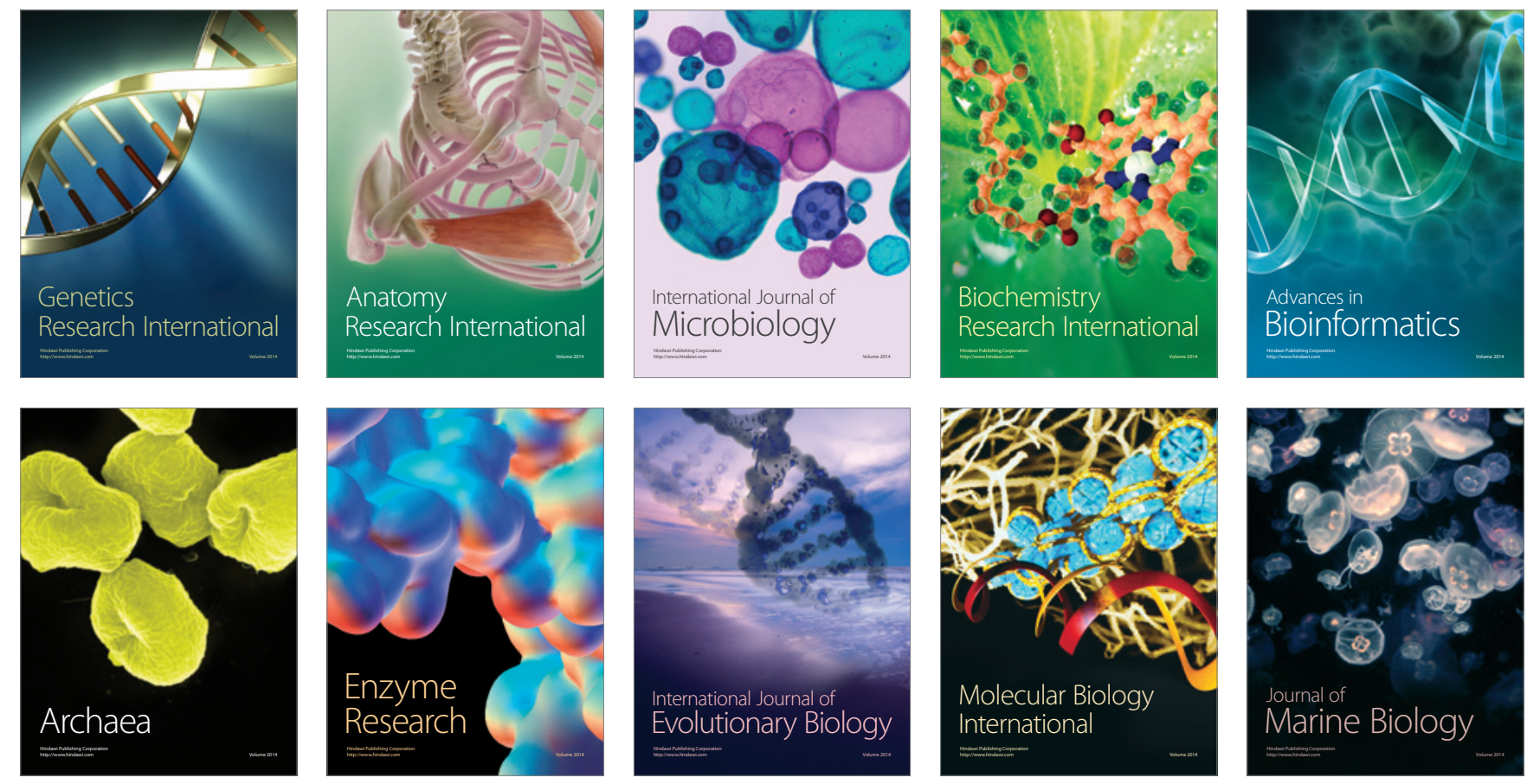